\title{
Evidence for a direct action of exogenous insulin on the pancreatic islets of diabetic mice: islet response to insulin pre-incubation
}

\author{
C. Gordon, A.P. Yates and D. Davies \\ Department of Clinical Endocrinology, Manchester Royal Infirmary, Manchester, UK
}

\begin{abstract}
Summary. Pancreatic islets were isolated by collagenase digest from normal $(+/+)$ and severely diabetic $(\mathrm{db} / \mathrm{db})$ mice of the $\mathrm{C} 57 \mathrm{BL} / \mathrm{Ks}$ strain. Batches of islets from the diabetic mice were incubated for $1 \mathrm{~h}$ at $37^{\circ} \mathrm{C}$ in Krebs-Ringer medium containing glucose $(3 \mathrm{mmol} / \mathrm{l})$, with or without mouse insulin $(50 \mathrm{mU} / 1)$, before perifusion. When compared with untreated islets from the same digest, pre-incubation of islets from diabetic mice with insulin elicited a restoration of the biphasic insulin response to a glucose challenge which was indistinguishable from the response of the untreated, control islets from
\end{abstract}

non-diabetic mice. Untreated diabetic islets showed no insulin response to glucose challenge, insulin values being very significantly lower than those of either non-diabetic or treated diabetic mouse islets $(p=<0.005$ ). The restoration of secretion in treated islets of diabetic mice was shown not to be an artefact. These observations provide evidence for a direct, as yet undefined, action of insulin on the $\beta$ cell of the diabetic mouse.

Key words: Diabetic mouse, C57BL/Ks-db/db, isolated islets, perifusion, insulin pre-incubation, biphasic insulin release.
Studies in non-insulin-requiring diabetic subjects have shown that treatment with supplementary exogenous insulin leads to an improvement of $\beta$-cell function [1,2]. Results of other studies have suggested that in newly diagnosed diabetics patients, insulin treatment may lead to a functional recovery of the $\beta$ cell rather than a major change in peripheral insulin resistance concomitant with better metabolic control [3, 4]. Similarly, continuous infusion of insulin into congenitally diabetic Chinese hamsters promotes an improvement of glucosemediated insulin secretion during subsequent perfusion of the pancreas in vitro [5]. This increase in glucose-mediated endogenous insulin secretion has been attributed to a resting of the stressed islet, by the near normoglycaemia of treatment, allowing $\beta$-cell recovery $[2,5]$.

The investigation described here, however, was designed to assess the direct effect of insulin on the $\beta$ cells of diabetic mice in the absence of any compromising humoral factors. This was carried out using perifusion of isolated islets of normal and diabetic C $57 \mathrm{BL} / \mathrm{Ks}$ mice, a strain showing congenital diabetes.

\section{Materials and methods}

Diabetic mice of the $\mathrm{C} 57 \mathrm{BL} / \mathrm{Ks} \mathrm{db}-\mathrm{db}$ strain were obtained from OLAC 1976 Ltd., Bicester, Oxon., UK. Normal mice of the C57BL/ $(+/+)$ strain were obtained from the Manchester University breed- ing colony, Hope Hospital, Salford. All mice used in the experiments were male aged between 24 and 28 weeks.

Insulin estimation was carried out by sensitive radioimmunoassay techniques using mouse insulin standard (Novo Research Institute, Bagsvaerd, Denmark), insulin binding reagent RD12 (Wellcome, London) and ${ }^{125}$ I iodinated insulin IM38 (Amersham International, Amersham, Bucks, UK).

A modified Krebs-Ringer bicarbonate medium was used, buffered with $20 \mathrm{mmol} / 1 \mathrm{~N}$-2-hydroxyethylpiperazine- $\mathrm{N}^{1}$-2-ethanesulphonic acid (HEPES; Sigma, St. Louis, Missouri, USA), and containing $0.5 \%$ $(\mathrm{w} / \mathrm{v})$ bovine serum albumin (BSA CohnV; Miles Biochemicals Slough, Bucks, UK). Collagenase (Worthington CLS IV) was obtained from Millipore, Harrow, Middlesex, UK. All other chemicals were of analytical grade and purchased from BDH Chemicals, Poole, Dorset, UK.

\section{Sample collection and blood glucose esimation}

All animals were fed with standard laboratory diet ad libitum except before blood glucose and insulin estimation, when the animals were fasted overnight.

Blood was collected from a tail vein into a heparinised capillary tube. For glucose estimation, $10 \mu \mathrm{l}$ of blood was placed on the pad of a Dextrostix reagent strip (Ames, Miles Laboratories, Slough, Bucks, UK). The colour reaction was read at the appropriate time on a Glucochek reflectometer (Medistron, Crawley, Surrey, UK). This system was validated by comparing Glucochek values for a number of samples with those obtained using a routine colourimetric method for glucose estimation [6].

A further $80-100 \mu \mathrm{l}$ of blood was transferred to a polypropylene microcentrifuge tube containing approximately $5 \mu \mathrm{l}$ of a $2 \%$ oxalate solution as the anti-coagulant, and after subsequent centrifugation the plasma was stored at $-20^{\circ} \mathrm{C}$ before insulin estimation. 


\section{Pancreatic tissue}

Animals were sacrificed by cervical dislocation and the pancreas removed and placed in ice-cold Krebs-Ringer medium gassed with $95 \%$ $\mathrm{O}_{2}: 5 \% \mathrm{CO}_{2}$.

Pancreatic islets were isolated by collagenase digest [7] and placed in batches of 25 onto support grids of organ culture dishes [8]. Groups of islets from diabetic mice from the same digest were pre-incubated for $1 \mathrm{~h}$ at $37^{\circ} \mathrm{C}$ in $0.8 \mathrm{ml} \mathrm{Krebs-Ringer} \mathrm{medium} \mathrm{containing} \mathrm{either} \mathrm{glu-}$ cose alone $(3 \mathrm{mmol} / \mathrm{l})$ or glucose $(3 \mathrm{mmol} / \mathrm{l})+$ mouse insulin $(50 \mathrm{mU} / \mathrm{l})$. After pre-incubation the islets were transferred to the perifusion cell [8] and equilibrated with either glucose $(3 \mathrm{mmol} / \mathrm{l})$ or glucose $(3 \mathrm{mmol} / \mathrm{l})+$ insulin $(50 \mathrm{mU} / \mathrm{l})$ for $30 \mathrm{~min}$. The perifusion cell was voided twice [8] and the islets washed for $10 \mathrm{~min}$ with glucose medium $(3 \mathrm{mmol} / 1)$. Samples were collected for a further $10 \mathrm{~min}$ at this glucose concentration (flow rate: $0.75 \mathrm{ml} / \mathrm{min}$ ) to establish basal insulin levels. The glucose concentration was then raised to $15 \mathrm{mmol} / 1$ in a square-wave challenge and samples were collected at 2-min intervals for $60 \mathrm{~min}$, after which the glucose concentration was returned to $3 \mathrm{mmol} / 1$ for a final $10 \mathrm{~min}$. All operations were carried out at $37^{\circ} \mathrm{C}$. The perifusate samples were stored at $-20^{\circ} \mathrm{C}$ before insulin estimation.

A series of experiments was performed in which batches of 25 islets from diabetic mice were pre-incubated as above, but with ${ }^{125} \mathrm{I}$ labelled insulin $(50 \mathrm{mU} / 1 ; 3.7 \mathrm{MBq})$. The islets were transferred to the perifusion cell and perifused with the same labelled medium for $30 \mathrm{~min}$. The perifusion cell was voided twice [8] to clear the labelled medium from the chamber and the islets washed by further perifusion with glucose medium ( $3 \mathrm{mmol} / \mathrm{l})$ alone for $10 \mathrm{~min}$. After this time, the standard perifusion regime was carried out as above. Radioactivity in the medium was monitored throughout all operations, and residual radioactivity in the islets was measured directly after termination of the experiments.

Table 1. Fasting blood glucose and plasma insulin concentrations and body weights of diabetic $(\mathrm{db} / \mathrm{db})$ and normal $(+/+)$ mice at the time of islet isolation

\begin{tabular}{lllcl}
\hline $\begin{array}{l}\text { Type of } \\
\text { mice }\end{array}$ & $\begin{array}{l}\text { Age } \\
(\text { weeks })\end{array}$ & $\begin{array}{l}\text { Weight } \\
(\mathrm{g})\end{array}$ & $\begin{array}{l}\text { Blood glucose } \\
(\mathrm{mmol} / \mathrm{l})\end{array}$ & $\begin{array}{l}\text { Insulin } \\
(\mathrm{mU} / \mathrm{l})\end{array}$ \\
\hline$(+/+)(n=14)$ & $27 \pm 0.3$ & $30.5 \pm 0.9$ & $6.3 \pm 0.4$ & $17 \pm 5.9$ \\
db-db $(n=7)$ & $26 \pm 0.7$ & $31.9 \pm 2.1$ & $20.6 \pm 1.9$ & $18 \pm 3.6$ \\
\hline
\end{tabular}

Values are given as mean \pm SEM

\section{Insulin assays}

Estimation of insulin levels in the perifusate was performed by a modification of the double-antibody method of Morgan and Lazarow [9]. The final incubation volume was $0.3 \mathrm{ml}$ and incubation was carried out at $4{ }^{\circ} \mathrm{C}$ for $18-24 \mathrm{~h}$. After centrifugation at $2000 \mathrm{~g}$ for $20 \mathrm{~min}$, the bound tracer was counted on a crystal scintillation counter (LKB Wallac, Turku, Finland).

Estimation of insulin levels in the mouse plasma samples was carried out by essentially the same method, except that the following modifications applied. The volume of the standard solutions and the plasma samples added to the incubation tubes was reduced from $100 \mu \mathrm{l}$ to $10 \mu \mathrm{l}$. Insulin free plasma $(10 \mu \mathrm{l})$ was added to all standard tubes and the equivalent amount of buffer added to all sample tubes. The lyophilised insulin binding reagent was reconstituted and made up to $30 \mathrm{ml}$ volume with buffer rather than the recommended $8 \mathrm{ml}$, in order to increase sensitivity. Similarly, the amount of labelled insulin added to each tube was reduced from 25 to $12.5 \mathrm{pg}$.

The assay was validated by substituting for the mouse insulin standard, the WHO first international reference preparation of human insulin and carrying out multiple estimations of a three level radioassay control human serum (Lyphocheck; Bio-Rad Laboratories, Watford, Herts, UK).

\section{Statistical analysis}

Results are expressed as mean \pm SEM. Differences were tested for statistical significance with either the paired or unpaired Student's t-test where applicable. All data processing was carried out using a CBM 8096 microcomputer (Commodore Business Machines, Santa Clara, California).

\section{Results}

\section{Insulin and blood glucose estimations}

The control values obtained using the microassay for insulin were well within the known concentration ranges of the commercial control serum at each level. Similarly, when a number of fasting and random blood samples

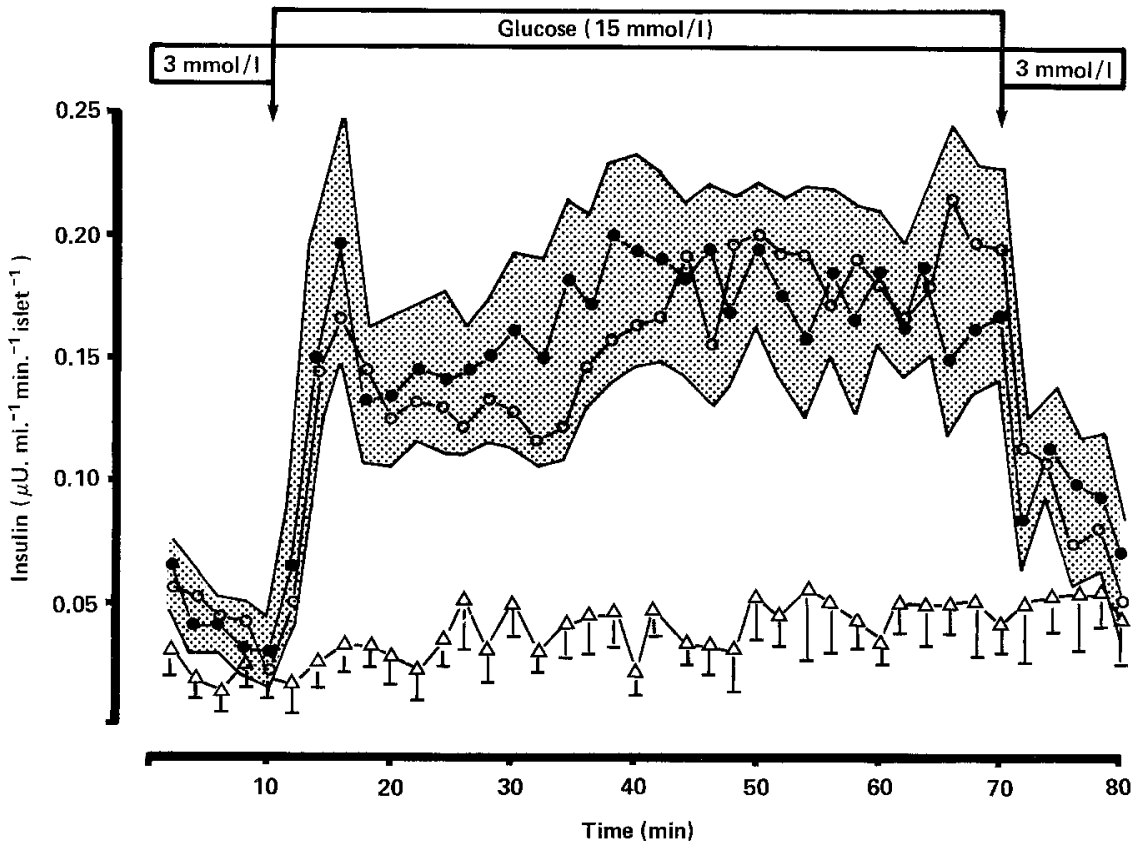

Fig. 1. Perifusion of islated pancreatic islets from non-diabetic $(+/+)$ mice $(\mathrm{O}-\mathrm{O}$; $n=14)$, and from diabetic C57BL/Ks (db-db) mice; (1) untreated $(\Delta-\Delta ; n=7)$ (2) after preincubation with mouse insulin (50 mU/1) for $1 \mathrm{~h}$ (๑ $; n=11$ ). Values shown are mean \pm SEM, the shaded area is equivalent to \pm SEM for the respective curves 
were taken and the glucose concentration of each estimated using Glucochek and the routine colourimetric assay, a good correlation was found; with no significant difference between the methods $(r=0.85 ; n=10)$.

Using the above methods, but with mouse insulin replacing human as the microassay standard, insulin and blood glucose estimations were carried out both on diabetic and non-diabetic mice over periods of between 12 and 28 weeks.

The db-db mice exhibited significant hyperglycaemia from the first examination until the time of islet isolation ( $p<0.0005$; Table 1$)$. The plasma insulin levels of the $\mathrm{db}-\mathrm{db}$ mice before sacrifice were not significantly different from the non-diabetic animals, similarly there was no difference in the final body weights of the two groups (Table 1). However the diabetic animals had shown a significant fall in both fasting plasma insulin and body weight respectively, from the values obtained at age 15 weeks $(53 \pm 15 \mathrm{mU} / 1 ; 42 \pm 0.6 \mathrm{~g} ; n=10 ; p<$ 0.05 ) concomitant with a general decline in condition and behaviour. Also the control non-diabetic animals exhibited a significant rise in plasma insulin values after feeding $(45 \pm 6 \mathrm{mU} / 1 ; n=8 ; p<0.05)$ but the $\mathrm{db}-\mathrm{db}$ mice did not $(23 \pm 5 \mathrm{mU} / 1 ; n=5)$.

\section{Islet isolation}

There were no significant differences in the numbers of islets isolated from the pancreas of diabetic $(160 \pm 9$ islets; $n=10)$ and non-diabetic mice $(138 \pm 7 ; n=16)$. The islets from the diabetic mice were found to be slightly smaller $(130 \pm 9 \mu \mathrm{m} ; n=20)$ than those from control animals ( $160 \pm 14 \mu \mathrm{m} ; n=30)$, but not significantly so, and also appeared to contain more vacuoles and fewer cells staining for insulin than did non-diabetic islets, when viewed under the optical microscope.

\section{Perifusion studies}

The results of perifusion of untreated pancreatic islets from diabetic (db-db) and non-diabetic $(+/+)$ mice are shown in Figure 1. Islets of the normal non-diabetic mice exhibited the usual biphasic insulin response to a square wave glucose challenge. When islets from the diabetic mice were perifused, the basal insulin levels (before and after challenge) were not significantly different from islets of normal mice. However, no insulin response could be demonstrated in answer to the stimulus of the higher glucose concentration. The insulin levels observed during this period were significantly lower than those of the normal non-diabetic mice $(p<0.005)$.

When islets from diabetic mice were pre-incubated with mouse insulin $(50 \mathrm{mU} / 1)$ before perifusion, no significant differences could be found between the insulin responses to a subsequent glucose challenge of these treated islets and normal non-diabetic controls (Fig.1). Untreated islets from the same preparations from diabetic mice exhibited no increased insulin secretory response.
The mean total amounts of insulin secreted during the $60 \mathrm{~min}$ of the high glucose stimulation were $239 \pm$ $28 \mu \mathrm{U}$ for islets from untreated non-diabetic mice and $247 \pm 47 \mu \mathrm{U}$ for islets from treated diabetic mice. Both were significantly higher than the corresponding value of $60 \pm 7 \mu \mathrm{U}$ for the untreated diabetic group $(p<0.005$; Fig. 1).

\section{Perifusion with radiolabelled insulin}

Islets from $\mathrm{db}-\mathrm{db}$ mice were pre-incubated and then perifused with radiolabelled insulin. As would be expected the initial washout from the perifusion cell contrained measurable radioactivity. However during the ( $3 \mathrm{mmol} / \mathrm{l}$ ) glucose baseline period, the radioactivity in the perifusate fell to a level equivalent to an insulin value of $0.004 \pm 0.001 \mu \mathrm{U} \cdot \mathrm{ml}^{-1} \cdot \mathrm{min}^{-1}$ per islet $(n=4)$. On changing to the $15 \mathrm{mmol} / 1$ stimulatory glucose medium, the radioactivity in the perifusate was barely measurable, being equivalent to a labelled insulin concentration of $0.0008 \pm 0.0001 \mu \mathrm{U} \cdot \mathrm{ml}^{-1} \cdot \mathrm{min}^{-1}$ per islet $(n=4)$. This value was obtained during the period of the perifusion at which the stimulated endogenous concentration was $0.2 \pm 0.05 \mu \mathrm{U} \cdot \mathrm{ml}^{-1} \cdot \mathrm{min}^{-1}$ per islet $(n=4)$. The amount of residual radioactivity within the islets after termination of the perifusion was equivalent to $0.3 \pm$ $0.09 \mu \mathrm{U} /$ islet radiolabelled insulin.

\section{Discussion}

The pathophysiology of the diabetic mutation of the $\mathrm{C} 57 \mathrm{BL} / \mathrm{Ks}$ strain of mouse has been studied extensively [10-14]. After a transient period of hyperinsulinaemia the animals, at 16-27 weeks, pass into what is clinically an insulin-requiring diabetic state, with severe hyperglycaemia, falling insulin levels, weight loss, ketonuria, neuropathy and microvascular changes.

The values presented here for blood glucose and insulin levels from the diabetic animals are compatible with those found by other workers during this severe phase of the disease $[10,12,13]$. Animals died at 28-30 weeks, presumably from insulinopenic diabetes.

The pancreas of the severely diabetic mouse has been shown to contain a mixture of islets with various structural abnormalities. These include near normal islets with $\beta$-cell degranulations, islets with proliferating ducts invading the cell mass, and islet-like configurations containing mainly ducts, acinar cells and fibrocollagen $[10,11]$. It is therefore possible that during collagenase digest and isolation some bias in islet selection could have occurred. However, this does not alter the fact that, during perifusion, the islets of diabetic mice showed no response above baseline insulin levels (Fig. 1) when challenged with glucose. Berglund et al. [13] also demonstrated this lack of response to increased glucose concentrations with both microdissected islets and, more pertinently, whole perfused pancreas from 
diabetic C57BL/Ks db-db mice. The islets from our normal non-diabetic C57BL mice showed the well documented biphasic insulin response to a glucose challenge during perifusion [15]. When islets from severely diabetic mice were pre-incubated with insulin and perifused in the same regime, a restoration of the first and second phases of insulin release in response to a glucose challenge was demonstrated.

Having demonstrated this restoration of function, it must be determined whether it is an artefact or a truly physiological response.

C-peptide estimation, the obvious first test for de novo insulin synthesis, is highly species specific, and no reliable data could be obtained from the human radioimmunoassay methods available to us.

It could be argued that the increased insulin release from the pre-incubated islets may be due to the tissue adsorbing insulin from the incubation medium and rereleasing it during perifusion, although the total amount of insulin secreted by the treated islets exceeded the total added insulin in the incubation by a factor of at least $\times 3$. However, this hypothesis was tested using ${ }^{125} \mathrm{I}-\mathrm{la}-$ belled insulin. When islets from diabetic mice were perifused after pre-incubation with labelled insulin, the barely detectable levels of radioactivity in the perifusate, equivalent to labelled insulin, were a factor of 25 times lower than the concentration of unlabelled endogenous insulin released during the glucose challenge. However, residual radioactivity was found within the islet tissue at the end of both the batch incubations and the perifusion studies and this may be due to some degree of internalization and degradation of the labelled insulin during pre-incubation.

The addition of an iodine atom to the insulin molecule may have steric effects on the structure and binding capacity of insulin. However, ${ }^{125} \mathrm{I}$-insulin has been shown to bind specifically to various membrane insulin receptors $[16,17]$ and has been shown to have full biological activity, stimulating glucose oxidation in fat cells [17].

Infusion of insulin into non-insulin requiring diabetic subjects has been shown to improve $\beta$-cell function $[1,2]$. Other studies have demonstrated increased insulin release after insulin treatment in animal models $[5,18]$. Lowering blood glucose to within the normal range in diabetic hamsters, for a period of 2 weeks, using insulin infusion, has been shown to restore the first phase of insulin release on subsequent pancreatic perifusion [5].

This well described improvement in $\beta$-cell function has, almost exclusively, been attributed to a resting of the islet; i.e. a regranulation of the $\beta$ cell when relieved of hyperglycaemic stress.

However, we believe that the results described in this study are evidence for a direct, and as yet undefined, action of insulin on the $\beta$ cell from the diabetic mouse.
Acknowledgements. We would like to thank the Wellcome Foundation and the North Western Regional Health Authority for financial support for this study. Also, we are most grateful to Miss S.A. Evans for her excellent technical assistance.

\section{References}

1. Turner RC, McCarthy ST, Holman RR, Harris E (1976) Beta cell function improved by supplementing basal insulin secretion in mild diabetics. Br Med J 1: 1252-1254

2. Turner RC, Holman RR (1978) Beta cell function during insulin or chlorpropamide treatment of maturity onset diabetes mellitus. Diabetes 27 (Suppl 1): 241-246

3. Park BN, Soeldner JS, Gleason RE (1974) Diabetes in remission: insulin secretory dynamics. Diabetes $23: 616-623$

4. Enk B (1977) Insulin secretion in insulin requiring diabetes before and during insulin treatment. Acta Endocrinol 85: 559-570

5. Frankel BJ, Schmid FG, Grodsky GM (1979) Effect of continuous insulin infusion with an implantable seven day minipump in the diabetic Chinese hamster. Endocrinology 104: 1532-1539

6. Trinder P (1969) Determination of blood glucose using 4-amino phenazone as oxygen acceptor. J Clin Pathol 22: 246

7. Anderson A, Hellerstrom C (1972) Metabolic characteristics of isolated pancreatic islets in tissue culture. Diabetes 21 (Suppl 2): $546-554$

8. Yates AP, Gordon C (1982) A cell for perifusion studies of isolated tissues. Med Lab Sci 39: 399-401

9. Morgan CR, Lazarow A (1963) Immunoassay of insulin: Two antibody system. Diabetes 12:115-126

10. Hummel KP, Dickie MM, Coleman DL (1966) Diabetes: a new mutation in the mouse. Science 153:1127-1128

11. Like AA, Chick WL (1970) Studies in the diabetic mutant mouse: 1. Light microscopy and radioautography of pancreatic islets. Diabetologia 6: 207-215

12. Chick WL, Like AA (1970) Studies in the diabetic mutant mouse: III. Physiological factors associated with alterations in beta cell proliferation. Diabetologia 6: 243-251

13. Berglund O, Frankel BJ, Hellman B (1978) Development of the insulin secretory defect in genetically diabetic $(\mathrm{db} / \mathrm{db})$ mouse. Acta Endocrinol 87: 543-551

14. Coleman DL (1982) Diabetes-obesity syndromes in mice. Diabetes 31 (Suppl 1): 1-6

15. Cerasi E (1976) Insulin secretion. In: Luft R (ed) Insulin. Nordisk, Denmark pp 111-128

16. Schweitzer JB, Smith RM, Jarett L (1980) Differences in organisational structure of the insulin receptor on rat adipocyte and liver plasma membrane: role of disulphide bonds. Proc Natl Acad Sci 77: 4692-4696

17. Freychet P, Roth J, Neville DM (1971) Monoiodoinsulin: demonstration of its biological activity and binding to fat cells and liver membranes. Biochem Biophys Res Comm 43: 400-408

18. Portha B, Picon L (1982) Insulin treatment improves the spontaneous remission of neonatal streptozotocin diabetes in the rat. Diabetes 31: 165-169

Received: 6 August 1984

and in revised form: 29 January 1985

\section{Dr. C. Gordon}

Research Area

Multi-Purpose Building

Manchester Royal Infirmary

Oxford Road

Manchester M13 9WL

UK 